athletes at the cob stage of training Young Science Newsletter of the European National University of the Ukrainian Forest. 2018; 30: 175-184.

11. Kashuba VO, Lyugailo SS, Futorniy SM. Integration of the program of physical rehabilitation in the process of the first - third stages of training athletes in case of dysfunctions of systems and their organisms Sports medicine and physical rehabilitation. 2019; 1: 99-112. Doi: https://doi.org/10.32652/spmed. 2019.1.99-112.

12. Kashuba V, Lopatsky S. Theoretical and practical aspects of monitoring the spacious organization of people. Monograph. Ivano-Frankivsk: Vidavets Kushnir G.M., 2018. 232 p.

13. Kashuba V, Popadyukha Y. (2018) Biomechanics of spacious organization of people: modern methods and methods for diagnostics and renewal of damage: monograph. K.: Center for Educational Literature. $768 \mathrm{~s}$.

14. Mironyuk I, Guzak O. The peculiarities of non-xed destructive equipment of young athletes at the current stage Visnik of the Carpathian University. Series: Physical culture. 2019; 34: 87-93.

15. Samoilyuk O. Prophylactic and rehabilitation directly in the system of baggage training of young athletes with functional damage to the musculoskeletal system= Preventive and rehabilitation direction in the system of multiple training of youth sportsmen with functional disorders of the muscular apparatus. Journal of Education, Health and Sport. [Інтернет]. 2016; 6(8): 955-64. eISSN 2391-8306.

16. Kashuba V, Andrieieva O, Yarmolinsky L, Karp I, Kyrychenko V, Goncharenko Y, Rychok T, Nosova N. Measures to prevent functional muscular disorders in sports training of 7-9-year-old football players Journal of Physical Education and Sport (JPES). 2020; Vol 20 (Supplement issue 1), Art 52: 366-371.

17. Kashuba V, Savliuk S, Vypasniak I, Yavorskyy A, Kindrat P, Grygus I, Vakoliuk A, Panchuk I, HagnerDerengowska M. Differentiated approach for improving the physical condition of children with visual impairment during physical education Journal of Physical Education and Sport ${ }^{\circledR}$ (JPES). 2020; Vol 20 (Supplement issue 2), Art 136: 958-965. Doi: 10.7752/jpes.2020.s2133

\begin{tabular}{|c|c|}
\hline \multicolumn{2}{|l|}{ Цитування на цю статтю: } \\
\hline \multicolumn{2}{|c|}{$\begin{array}{l}\text { Третяк ДЯ, Іванишин ІМ. Структура моделі програми здоров’язберігаючої спрямованості на етапі } \\
\text { попередньої базової підготовки у юних футболістів з функціональними порушеннями опорно-рухового } \\
\text { апарату. Вісник Прикарпатського університету. Серія: Фізична культура. } 2020 \text { Листоп 24; 36: 68-74 }\end{array}$} \\
\hline Відомості про автора: & Information about the author: \\
\hline $\begin{array}{l}\text { Третяк Дмитро Ярославович - аспірант, ДВНЗ } \\
\text { “Прикарпатський національний університет імені } \\
\text { Василя Стефаника” (Івано-Франківськ, Україна) }\end{array}$ & $\begin{array}{l}\text { Tretyak Dmytro Yaroslavovych - post-graduate } \\
\text { student, Vasyl Stefanyk Precarpathian National } \\
\text { University (Ivano-Frankivsk, Ukraine) }\end{array}$ \\
\hline \multicolumn{2}{|l|}{ https://orcid.org/0000-0002-7025-671X } \\
\hline $\begin{array}{l}\text { Іванишин Ірина Мирославівна-кандидат хіміч- } \\
\text { них наук, доцент, ДВНЗ “Прикарпатський націо- } \\
\text { нальний університет імені Василя Стефаника" } \\
\text { (Івано-Франківськ, Україна) }\end{array}$ & $\begin{array}{l}\text { Ivanyshyn Iryna Myroslavivna-Candidate of Scien- } \\
\text { ce (Chemistry), Associate Professor (Ph. D.), Vasyl } \\
\text { Stefanyk Precarpathian National University (Ivano- } \\
\text { Frankivsk, Ukraine) }\end{array}$ \\
\hline $\begin{array}{l}\text { e-mail: Iraivan68@gmail.com } \\
\text { https://orcid.org/0000-0003-1765-8311 }\end{array}$ & \\
\hline
\end{tabular}

УДК 796.11.3:658 doi: 10.15330/fcult.36.74-86

Роман Тягур, Володимир Мисів, Ігор Матійчук

\title{
МЕНЕДЖЕР У ФІЗИЧНІЙ КУЛЬТУРІ: ПЛАНУВАННЯ ОСОБИСТОЇ ДІЯЛЬНОСТІ
}

\author{
Час - найобмеженіший капітал, і якщзо не можеш ним \\ розпоряджатися, не зможеш розпоряджатися нічим іншим.
}

Пітер Друкер

\begin{abstract}
Мета. Розкрити роль та значення планування у роботі менеджера, охарактеризувати зміст планування особистої праці менеджера у фізичній культурі. Методи. Для реалізації поставленої мети були використані наступні методи дослідження: теоретичний аналіз і узагальнення науково-методичної літератури. Результати. Встановлено, що функиї менеджера у фізичній культурі багатогранні: загальне керівництво діяльністю організації, координація дій підрозділів і служб, робота з кадрами, визначення цілей $і$ завдань діяльності, прийняття рішень, представниџтво організації у стосунках з інши-
\end{abstract}

(C) Тягур Р., Мисів В., Матійчук I., 2020 
ми організаціями, контроль за діями виконавців. Виконання зазначених функцій потребує від менеджера високих ділових і особистих якостей. Доведено, щчо час - один із ресурсів, який не відновлюється. Брак часу на виконання поставлених завдань веде до штучного продовження робочого дня, нераціонального його використання. Брак часу - ие результат відсутності чіткості, плановості та організованості роботи менеджерів. Показано, щчо уміння раціонально використовувати робочий час, постійно вдосконалювати процес його планування - ознака організованого менеджера. Планувати особистий робочий час менеджера необхідно так само, як і всі інші види діяльності організації, в тому числі $і$ ресурси. Розкрито особливості планування особистої праці менеджера у фізичній культурі. Процес планування праці менеджера має починатися з вибору ним особистих иілей. Визначивщи цілі менеджер складає такі плани: починаючи з річних - конкретизує місячні - далі на тиждень - завершує щзоденними. Висновок. Планування робочого часу менеджера з фізичної культури має здійснюватися з урахуванням раціонального чергування проблем, які необхідно вирішити. Спочатку слід планувати справи: з фіксованим терміном виконання; ті, щчо вимагають значних витрат часу; неприємні справи, відкладати які на потім небажано. Далі планується рутинна робота і виконання повсякденних обов'язків. Третє місце відводиться другорядним і епізодичним справам.

Ключові слова: планування, менеджер у фізичній культурі, діяльність.

The purpose of this study is to reveal the character and importance of planning in the manager's work, to characterize the content of planning the personal work of the manager in physical culture.

To achieve this goal, the following research methods were used: theoretical analysis and generalization of scientific and methodological literature.

Results. It is established that the functions of the manager in physical culture are multidimensional: general management of the organization, coordination of departments and services, work with personnel, defining the goals and objectives of the activity, decision making, representation of the organization in relations with other organizations, control over the actions of executors. The performance of these functions requires a manager of high business and personal qualities.

It is proved that time is one of the resources that never recover. Lack of time to complete the tasks leads to the extension of the working day and its irrational use. Lack of time is a result of the lack of clarity, timeliness, and organization of the manager's work.

It is shown that the ability to economically and rationally use working hours, constantly improve the process of planning is a sign of an organized manager. It is necessary to plan the personal working hours of the manager in the same way as all other activities of the organization, including resources.

Features of planning of personal work of the manager in physical culture are revealed. The process of planning a manager's labor should begin with choosing his personal goals. Having defined goals, the manager makes the following plans: starting with the annual goals he specifies goals for every month, week, and day.

Conclusion. The scheduling of the manager's working hours should be made with taking into account the rational alternation of problems to be solved. First, you should plan the cases: with a fixed deadline; those that take considerable time; unpleasant things that can not be put off for later. Next on the list is to plan routine work and day-to-day responsibilities. Third place is assigned to minor and episodic cases.

Keywords: time, personal goals, planning tools, organized manager.

Постановка проблеми та аналіз результатів останніх досліджень. Менеджер $\epsilon$ центральною фігурою апарату управління, від результативності його праці залежить успішність системи управління організацією у сфері фізичної культури. Менеджер діє на підставі принципу єдиноначальності, наділений широкими повноваженнями і правами, але водночас несе відповідальність за результати роботи організації [3].

Функції менеджера багатогранні: загальне керівництво діяльністю організації, координація дій підрозділів і служб, робота з кадрами, визначення цілей і завдань діяльності, прийняття рішень, представництво організації у стосунках з іншими інституціями, контроль за діями виконавців. Реалізація зазначених функцій вимагає від менеджера високих ділових і особистих якостей [4].

Важливою якістю менеджера 3 фізичної культури є вміння реагувати на зміни, які відбуваються в організації і поза нею, часто за умов дефіциту інформації і часу. У зв'язку з цим виникає небезпека помилкових рішень. 
Менеджери, які постійно відчувають тиск власників, вищих менеджерів, підлеглих, споживачів, ділових партнерів зазнають стресу, що негативно позначається як на ефективності їхньої праці, так і здоров”і [2].

Причиною неефективної роботи багатьох менеджерів, особливо початківців, $\epsilon$ невміння розпоряджатися часом. Такі менеджери прагнуть виконати усі завдання самостійно, встигнути на усі наради, прийняти усіх відвідувачів, глибоко вникнути в усі питання діяльності організації. Вони приїжджають на роботу першими і залишають роботу останніми. Проте, чимало справ залишається невиконаними. Будь-яка діяльність має мати мету і здійснюватися за раніше складеним планом. Звичайно, це стосується і праці менеджера. Адже функція управління планування полягає у встановленні цілей і визначенні шляхів їх досягнення [1].

Отже, процес планування праці менеджера має починатися з вибору ним особистих цілей. Ціль - це те, до чого прагнуть, орієнтир, який треба досягти. Вона визначає кінцевий результат. Необхідно усвідомлювати, що тут мається на увазі не те, що ми робимо, а те, заради чого ми це робимо. Ціль - це свого роду виклик, що спонукає до дій; це конкретний стан певних характеристик організації, досягнення яких $є$ бажаним i на досягнення яких спрямована діяльність даної організації. Навіть найкращий спосіб роботи є марним, якщо ми заздалегідь чітко не визначимо те, чого прагнемо. У свою чергу, щоб визначити цілі, треба думати про майбутнє. Ціль дає зрозуміти, у якому напрямку необхідно рухатися. Значимість цілей дуже важко пере-оцінити. Цілі є вихідною точкою планування діяльності, цілі лежать в основі побудови організаційних відносин, на цілях базується система мотивації, яка використовується в організації, крім того, цілі є відправною точкою в процесі контролю та оцінки результатів праці окремих працівників, підрозділів та організації в цілому [6].

Мета дослідження - розкрити роль, значення та зміст планування менеджера у фізичній культурі.

Методи дослідження - теоретичний аналіз і узагальнення науково-методичної літератури.

Результати дослідження. Менеджер, який не вміє розпоряджатися часом, нездатний побачити перспективу за безліччю повсякденних турбот. Врешті ефективність його праці мінімальна, виникає відчуття незадоволеності собою, підлеглими, невпевненості у власні сили. Причиною цього є невміння планувати роботу.

Для такого менеджера, характерні:

- безплановість у використанні робочого часу і слабке опрацювання ключових сфер діяльності;

- нервозність, поспіх і сумбурність у діях;

- нетерплячість у прийнятті рішень, у відносинах з рівними за рангом, $з$ підлеглими;

- недостатній рівень розподілу управлінської праці в підрозділах, низький ступінь делегування функцій і відповідальності підлеглим;

- відсутність порядку на робочому місці;

- надмірність і безсистемність роботи з документами, кореспонденцією, що надходить;

- використання принципу “що не встиг на роботі - дороблю вдома”.

Вітчизняні дослідження, у ході яких визначалися основні причини перевантаження менеджерів вищого і середнього рівнів і причини неефективного використання робочого часу, показали такі результати (у порядку їх значимості):

- недостатня кваліфікація управлінського персоналу - 66\%;

- невпорядкованість інформації - 50\%; 
- низький рівень комп'ютеризації праці в управлінні - 50\%;

- неорганізованість виробничих процесів - 32\%;

- нечіткий розподіл прав і обов'язків - 30\%;

- велика кількість нарад - 28\% [6, 9, 10, 17 ].

Аналіз використання робочого часу вітчизняними менеджерами 3 фізичної культури свідчить про наступне: тривалість робочого часу перевищує норму на 3 години, а корисна зайнятість при цьому складає всього 5-6 годин; заступників керівника на 2-3 години, а корисна зайнятість відповідно складає 5 і 6 годин. Менеджери підрозділів використовують час приблизно так само, як і головні фахівці. Коли йдеться про корисну зайнятість, то мається на увазі перелік завдань, видів діяльності, прийняття рішень, що входять у компетенцію тільки цих менеджерів.

Особливості часу як ресурсу: незворотність, неможливість купівлі та зберігання, заміни або збільшення обсягу. Таким чином, час - один з ресурсів, який не відновлюється. Брак часу на виконання поставлених завдань призводить до штучного продовження робочого дня, нераціонального його використання. Брак часу - це результат відсутності чіткості, плановості та організованості роботи менеджерів. Встановлено, що непередбачена трихвилинна телефонна розмова нерідко призводить до втрати 15-20 хвилин, необхідних для того, щоб знову зосередитись і відновити початкову працездатність.

Уміння раціонально використовувати робочий час, постійно удосконалювати процес його планування - ознака організованого менеджера з фізичної культури. Під плануванням робочого часу часто розуміють простий перелік поточних завдань на наступний день. Зважаючи лише на перелік завдань і не знаючи їх тривалості менеджери, у кращому випадку, обмежуються спробою оцінити обсяг майбутньої зайнятості без аналізу бюджету часу. Але урахування витрат робочого часу на виконання завдань дає можливість одержати повну картину завантаження. Планувати особистий робочий час менеджера необхідно так само, як і всі інші види діяльності організації та iii ресурси [7].

Планування покликане забезпечити раціональне використання найціннішого ресурсу - часу. Чим краще розподілений (тобто спланований) час, тим краще він може бути використаний в особистих і професійних інтересах менеджера. Планування, як складова частина раціональної організації особистої роботи менеджера, означає підготовку до реалізації іiі цілей і структурування часу. Планування щоденної роботи, середньо- і довгострокових завдань дозволяє не тільки раціонально використовувати час, але й досягти успіху і бути впевненим у собі [16].

Аналогічно тому, як організація планує стратегію своєї діяльності, кожна людина має думати про майбутнє і не піддаватися перебігу подій. Головна перевага планування роботи полягає в тому, що воно сприяє значній економії часу в цілому. Існує оптимум витрат часу на планування, після якого подальше збільшення часу на планування стає неефективним від загального планового періоду (рік, місяць, тиждень, день). Такий оптимум має складати не більше одного відсотка.

Успішна діяльність організації (федерації, спортивного клубу тощо) можлива лише за умови, що планування здійснюється цілеспрямовано. Проте, керівництво багатьох організацій через зайву самовпевненість не приділяє належної уваги розробці плану і тому змушене вдаватися до авторитарного управління, що спричиняє авральний режим роботи i, як правило, - заниження якості результату. Цілі таких менеджерів, зазвичай, змінюються щоденно, і їх спосіб роботи яскраво демонструє, як не треба реалізовувати план.

Якщо є впевненість, що завдання є добре вивченим і достатньо простим для вирішення без застосування формальних методів планування, то ця обставина виправ- 
довує прагнення заощадити час на плануванні та використати його для організації і координації. Тому деякі організації можуть досягти певного рівня успіху, не докладаючи значних зусиль на формальне планування. Більше того, тільки планування і сам план не гарантують успіху. Проте, формальне планування може створити ряд цінних i істотних чинників для успіху організації. Практичне значення планування особистої роботи менеджера полягає у наступному:

1. Якщо комплекс робіт вирішує конкретне завдання та спрямований на кінцеві цілі управлінської діяльності, то якісно розроблені плани забезпечують їхнє досягнення. Планування визначає що, кого, коли, де, як, скільки і чого потрібно для досягнення даної цілі. Таким чином, воно є засобом створення ланки між встановленими цілями і шляхом їх реалізації.

2. Планування дозволяє оцінити практичні можливості досягнення цілей. Воно є єдиним засобом формального прогнозування майбутніх проблем і можливостей.

3. Планування полегшує пошук кращих і більш ефективних шляхів досягнення цілей організації.

4. Планування виявляє і встановлює зони потенційних проблем і несподіваних наслідків.

5. Планування забезпечує основи для оцінки витрат і розробки бюджетів, календарних планів і ресурсів.

6. Планування є основою для контролю. Щоб контроль був ефективним, його варто тісно пов'язати з плануванням. Такий зв'язок є дуже важливим для забезпечення ефективності процесу управління в цілому. Ефективний кількісний метод його здійснення - це складання графіків, розкладів і бюджету.

7. Планування допомагає визначити необхідні виробничі відносини. Оскільки сприяє формуванню загальних цілей у межах усієї організації.

8. Планування дозволяє передбачити чинники, які варто враховувати щодо досягнення цілей. Формальне планування сприяє зниженню ризику в процесі прийняття рішень [1].

Виділяють вісім складових планування.

Першою складовою планування є збільшення кількості завдань, їх комплексність. Виконана робота вносить свою частку, для вирішення завдання, а вирішення кожного завдання - для досягнення цілей організації. У плані концентруються усі прийняті рішення щодо досягнення цілей. Під час планування необхідно відповісти на такі запитання:що має бути зроблено?, коли це буде зроблено?,хто це буде робити?, де це буде зроблено? що для цього необхідно?

Комплексність спричиняє необхідність спеціалізації, а оскільки кожен спеціаліст “розмовляє своєю мовою”, відповідає за свою сферу діяльності організації, має свою точку зору, то спеціалізація може спричинити порушення узгодженості дій. Тому необхідно об'єднати думки усіх спеціалістів, аби скоординувати їхні дії щодо досягнення цілей організації.

Друга складова планування - це збільшення значення часу. Якщо організація хоче вирішити певну проблему раніше за конкурентів, то вона має здійснити відповідні заходи у терміни, що передбачаються в планах.

Третьою складовою планування є обмеженість ресурсів. План має бути розробленим так, щоб використання обмежених ресурсів було оптимальним і щоб ресурсами можна було маневрувати.

Четверта складова. Важливу роль відіграють витрати, капітальні вкладення і їхня рентабельність. Проект є непродуктивним доти, доки продукт не буде реалізо- 
ваним. Тому необхідно передбачити усі шляхи якомога швидшого отримання прибутку. Ця обставина ще раз підкреслює необхідність строгого дотримання плану.

П'ята складова. Внаслідок ускладнення виробничо-господарської діяльності через зростання цін і непередбачуваність економічної ситуації збільшується й елемент ризику реалізації цілей організації. Тому умовою фінансування плану реалізації цілей організації є не просто план, а план, який може бути реалізований.

Шоста складова. На процес реалізації плану, а отже і на досягнення цілей організації впливають різноманітні чинники. Необхідно заздалегідь запобігти впливу негативних чинників. Приймати ефективні рішення у будь-якій непередбаченій ситуації. Варто особливо підкреслити, що зміна плану та аналіз наслідків таких змін можливі тільки за умови існування самого плану. Тому при плануванні реалізації цілей організації формується основа для контролю і регулювання.

Сьома складова. Досягнення цілей організації залежить від внеску кожного. Планування істотно впливає на підвищення продуктивності праці.

Восьма складова. Існування плану забезпечує спадкоємність у роботі з реалізації цілей організації. Цінність планування і самого плану виявляється в процесі його виконання. Процес реалізації плану має порівнюватись із запланованими цілями, якщо виявлено недоліки, відхилення, збої то застосовуються корегувальні дії, які грунтуються на виборі таких управлінських рішень: усувати відхилення; переглянути стандарти та критерії; поєднати попередні підходи [5,12].

Встановлення цілей - це свідоме виконання своїх дій для їх реалізації. Встановлення цілей це постійний процес, оскільки в процесі діяльності менеджера може з'ясуватися, що ті або інші параметри змінилися, що призводить до необхідності зміни цілей. Саме в постановці цілей полягають основи діяльності організації і іiі успішне майбутнє. Якщо у менеджера є усвідомлена ціль, то туди ж спрямовані й усі неусвідомлені сили менеджера, тобто цілі сприяють концентрації сил на важливих напрямах діяльності.

Цілі менеджера мають відповідати таким вимогам:

1. Цілі мають бути досяжними.

Звичайно, цілі мають містити певний виклик для менеджера. Цілі не можуть бути досить легкими для досягнення. Але вони також не можуть бути нереальними, такими, що виходять за грані можливості менеджера. Нереальні цілі сприяють демотивації менеджера та втрати ним орієнтиру, що дуже негативно позначається на діяльності організації.

2. Конкретними і вимірюваними.

3. Цілі мають мати чітко встановлені терміни. Порушення термінів може оцінюватись як невиконання встановлених цілей.

4. Цілі мають бути взаємоузгодженими, не суперечливими.

Процес встановлення особистих цілей менеджера передбачає три етапи:

1. Визначення цілей. Насамперед, менеджер має визначити, чого він бажає досягти в особистому і професійному плані.

2. Аналіз можливостей досягнення встановлених цілей. На цьому етапі слід проаналізувати свої сильні і слабкі сторони, які можуть полегшувати або ускладнювати досягнення цілей, а також відповідність між цілями і наявними ресурсами. Менеджер має визначати, які ресурси він має інтерпретувати (часові, матеріальні, фізичні, здібності до мов) для досягнення цілей.

3. Уточнення і конкретне формулювання цілей. Для подальшого планування необхідно залишити тільки реальні для досягнення цілі. Вони мають бути також чітко 
сформульовані і мати часову характеристику. Пропонується встановлення довго- (життєві), середньо- (до 5 років) і короткострокові (до одного року) цілі [7].

Після встановлення цілей розпочинається власне планування праці менеджера. Менеджеру складно, або неможливо, складати конкретні плани на більш-менш тривалий період, оскільки під впливом всіляких непередбачуваних чинників їх доведеться постійно переглядати. Тому на практиці, як правило, обмежуються розробкою плану особистої роботи на день, тиждень, місяць. Причому план на місяць часто складають недосконало, зазначаючи в ньому лише невідкладні і найбільш важливі справи. На практиці планування часу зводиться до його розподілу за видами робіт. Укрупнений розподіл часу регламентується за допомогою розкладу робочого дня, який будується 3 урахуванням розкладу дня вищого керівництва, враховує періодичність виконання окремих робіт і здійснює їх узгодження. Треба мати на увазі, що з підвищенням рівня управління зменшується час, що витрачається на управління основною діяльністю, $\mathrm{i}$ зростає час на адміністративну, організаційну роботу, представництво, вирішення соціальних проблем.

Процес розробки плану особистої праці менеджера пропонується здійснювати за схемою, наведеною на рис. 1.

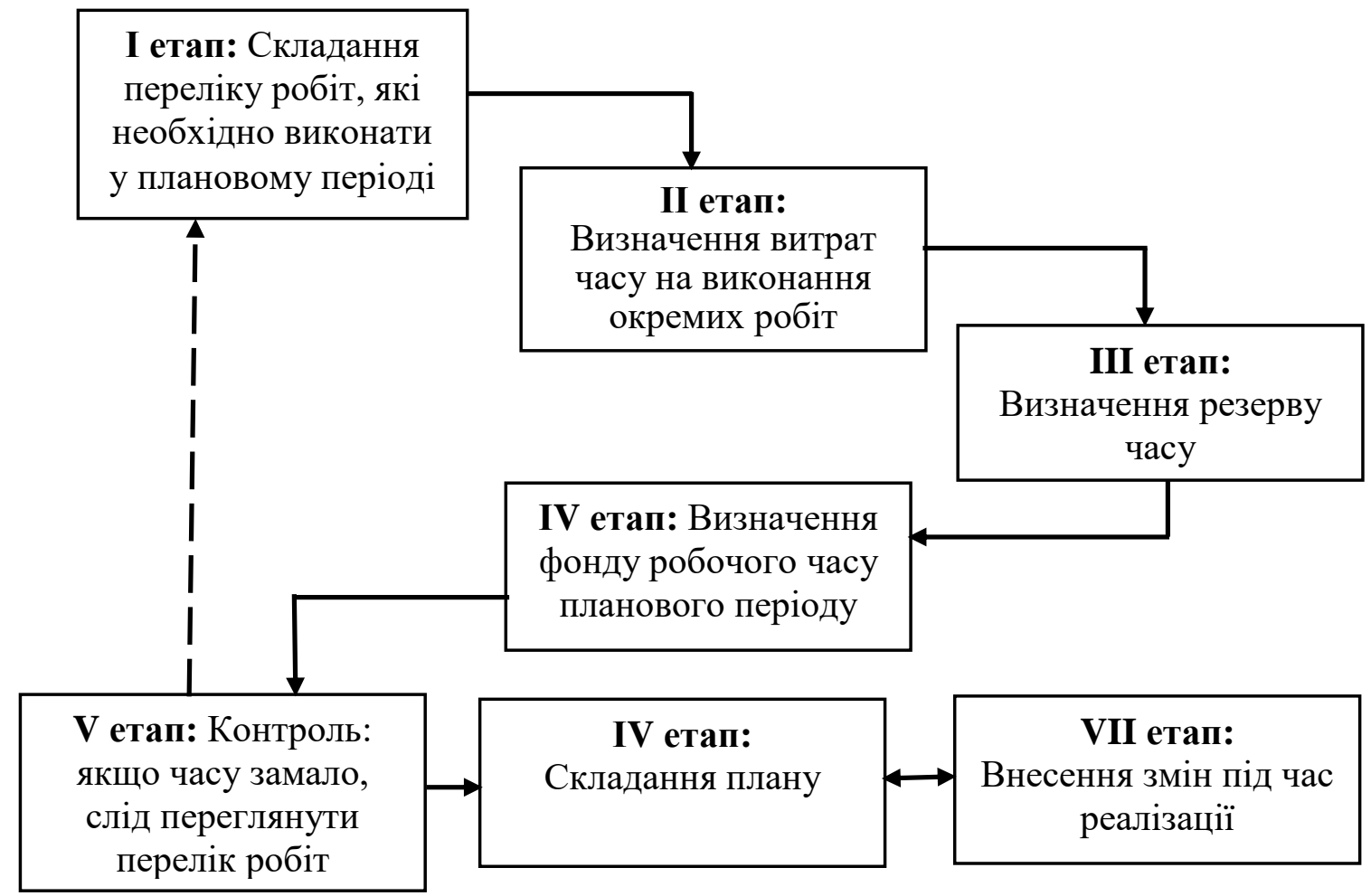

Рис. 1. Схема процесу планування особистої праці менеджера.

Щодо робочого часу менеджера, то його можна поділити на три частини:

- заплановані завдання - 60\% (виходячи з 8-годинного робочого дня, запланована активність не має перевищувати 5-6 год на день);

- резерв часу на непередбачувані завдання - 20\%;

- резерв часу на творчу діяльність менеджера і підвищення кваліфікації - 20\%.

Отже, співвідношення між плановим часом і резервом має становити $60: 40$. Завдяки встановленому резерву часу менеджер має змогу протягом планового періоду 
адекватно реагувати на можливі ускладнення в процесі реалізації тих або інших завдань, вирішувати непередбачувані завдання, займатися творчістю.

Практика свідчить, що планування особистої праці не потребує від менеджера значних витрат часу. Для складання плану досить витратити в кінці робочого дня 10-20 хв. Натомість переваги планування особистої праці перевищуватимуть ці витрати. Зокрема, раціональне планування особистої праці менеджера дає змогу скласти план на наступний день, чітко уявити завдання, упорядкувати роботу протягом дня, сконцентрувати увагу на найважливіших завданнях, само дисциплінує під час виконання завдань, дає відчуття успіху наприкінці робочого дня, підвищує задоволеність i мотивацію, і в цілому сприяє ефективності праці.

Добре зарекомендував себе і такий метод планування: планувати час таким чином, щоб щогодини 15 хв залишалися вільними і їх можна було б використовувати для телефонних дзвінків, підпису документів, непередбачених завдань і відпочинку. Завдяки цьому розпорядок дня стане гнучким, можна буде багато чого зробити понад план [4].

Під час планування особистої праці менеджер складає такі плани: починаючи 3 річних - конкретизує у місячні - далі до тижневих - завершує щоденними. Процес планування робочого дня (тайм-менеджмент) за методом “Альпи” включає такі стадії:

1. Складання переліку завдань.

2. Визначення витрат часу на виконання завдань.

3. Резервування часу (у відношенні 60:40).

4. Прийняття рішень за пріоритетами та передорученням певних завдань.

5. Контроль (урахування незробленого).

Якщо у результаті контролю виконання денного плану особистої роботи менеджера виявлені невиконані справи, слід проаналізувати необхідність їх виконання і в залежності від результату або перенести на наступний день, або делегувати, або відмовитися від виконання. Менеджер має постійно контролювати виконання особистого плану, що дає можливість виявляти резерви для подальшого удосконалення своєї роботи і раціонального використання робочого часу.

Застосування методу “Альпи” дозволяє менеджеру витрачати не більше 10 хв для складання щоденного плану. Позитивні сторони методу “Альпи”: кращий настрій на майбутній робочий день; чітке уявлення про завдання робочого дня; самодисципліна; зосередження на найбільш важливому; досягнення цілей дня; підвищення задоволеності і мотивації; щоденна економія 10-20\% робочого часу [7].

Планування робочого часу менеджера має здійснюватися 3 урахуванням раціонального чергування проблем, які необхідно вирішити.

До плану особистої роботи менеджера в першу чергу вносяться: справи з визначеним терміном виконання; справи, що вимагають значних витрат часу; неприємні справи, відкладати які на потім небажано. Далі планується рутинна робота і виконання повсякденних обов'язків. Третє місце відводиться другорядним і епізодичним справам (наприклад, читанню поточної кореспонденцій, обходу робочих місць) [2].

У будь-якому випадку під час планування встановлюється точний термін виконання завдання. Якщо у визначені терміни завдання виконати неможна, в плані передбачається можливість перенесення його на більш пізній період.

Особистий план роботи має бути реальним і не перевантаженим. Менеджеру слід виділяти години і дні тижня для виконання завдань, що систематично повторюються, (наради, розгляд пошти, прийом відвідувачів). Це дасть можливість налагодити такий ритм роботи, що дозволить заощадити значну кількість часу. 
Час для проведення нарад, конференцій, обговорень, зборів, засідань має бути мінімальним і в той же час достатнім для обміну інформацією. Цьому сприяє ретельна підготовка відповідного заходу.

Передумовами планування часу є його ретельне фіксування і контроль за його використанням, що дозволяє мати точне уявлення про нього, краще розподіляти на вирішення різноманітних завдань, а також узгоджувати свої дії з підлеглими і колегами.

За періодом планування розрізняють такі плани особистої праці менеджера:

1. Оперативні - планування часу (тижневі плани-графіки та графіки робочого дня).

2. Середньострокові (квартальні та плани на місяць).

3. Перспективні (річні плани) - планування результатів.

Під час складання середньострокових планів визначається: центральна, найбільш трудомістка проблема періоду (квартал, місяць), яка має бути вирішена в його межах; завдання, які необхідно розв'язувати; можливі труднощі; завдання, що виходять за його межі.

У місячних планах треба враховувати критичні дні і особисті біоритми - фізичний, емоційний та інтелектуальний, що припадають відповідно на 23, 28 і 33 дні. На позитивні фази цих періодів плануються справи, що вимагають підвищених навантажень.

Врахування принципу підвищеної працездатності необхідний і в плані на день. План на день має включати вирішення не більше 10 проблем, в тому числі не більше трьох першочергових, робота над якими здійснюється насамперед. Найбільш важливі, складні а також дуже неприємні справи доцільно планувати на найбільш сприятливу для працездатності менеджера частину доби. У більшості людей $є$ два піки працездатності: 39 до 13 і з 16 до 18 год. На цей час необхідно планувати найбільш складну і відповідальну роботу [ $3,4,13]$.

У залежності від характеру проблем доцільно планувати їхнє виконання з урахуванням періоду “нульової втомлюваності”, відомого в психології (з 8 до 12 години). Відповідно до цього проблемами, вирішення яких вимагає інтенсивних витрат розумової енергії і глибокого аналізу, варто займатися в дообідні години. Найменш продуктивний час можна відвести для нескладних і другорядних питань (розгляд пошти, прийом відвідувачів і т. д.). Рутинну роботу і так звані, “дрібниці” протягом робочого дня менеджеру рекомендується виконувати щодо пріоритетності, по можливості об'єднуючи однорідні завдання у робочі блоки. Це дозволяє не “перескакувати" з однієї проблеми на іншу і економити таким чином час.

Як і всі інші, план витрат часу на день має складатися в письмовій формі, оскільки таким чином закладені в ньому проблеми важче ігнорувати. Крім того, записи розвантажують пам'ять, дисциплінують, дозволяють чіткіше розподіляти роботу, робити іiї більш цілеспрямованою. За записами також легше контролювати виконання плану і оцінювати його підсумки.

Складання плану на день слід починати напередодні у декілька етапів, спочатку формуються його завдання, перенесені з місячного, тижневого (на декаду) планів, невирішені завдання з плану попереднього дня, завдання, що не планувалися заздалегідь внаслідок повторюваності; непередбачувані завдання. Витрати часу на них розподіляються 3 урахуванням ефективного способу їх вирішення. У плані на день передбачаються “вікна", на випадок необхідності вирішувати несподівані завдання і десяти хвилинні перерви після кожної години роботи.

Потім ще раз визначається пріоритетність завдань: виділяються ті з них, які треба вирішити негайно і делегуються підлеглим, які будуть їх виконувати. Вранці 
складений напередодні план на день обговорюється менеджером з секретарем, щоб врахувати непередбачувані обставини. Як і будь-який інший план, план на день, щодо використання часу, має бути гнучким: строго в ньому регламентуються тільки питаня, пов'язані із різноманітними нарадами, спілкуванням з відвідувачами $[7,17]$.

Вважається, що робочий день доцільно починати в один і той же час, оскільки людина - раб своїх звичок. Це забезпечує хороший тонус і дозволяє реалізовувати принцип “людина - господар роботи, а не робота - господар людини” [4].

Важливо, щоб менеджер починав свій робочий день раніше підлеглих, до їх приходу, міг уточнити завдання і вжити заходів для подолання труднощів. Після цього виконуються найбільш важкі і неприємні справи, а у другій половині дня - нескладні. Така послідовність зумовлена не тільки наростанням втоми, але і тим, що після обіду підлеглі, як правило, приходять з проханнями про допомогу у вирішенні тих чи інших питань. Тому у другій половині робочого дня краще займатися нескладними справами.

Для економії часу необхідно уникати імпульсивних вчинків щодо проблем, які виникли. Їх доцільно зафіксувати і розв'язувати пізніше, що дозволить завершити почате і краще усвідомити їх сутність.

Варто мати на увазі, що багато заходів у роботі менеджера щорічно повторюються. Тому секретар або особисто менеджер може визначити на день, декаду, місяць перелік таких повторюваних заходів:

- загальні збори, засідання та ін.;

- поточні наради щодо виконання функцій управління виробничо-господарською діяльністю;

- робота з групами працівників і окремими працівниками;

- важливі змагання, виставки, ярмарки, конференції, симпозіуми і т. п.

Чимала кількість днів у році уже буває зайнятою. Це варто враховувати під час тижневого і місячного планування. Важливо вирішити, на яких заходах менеджер буде присутній особисто, а на яких його може замінити підлеглий.

Маючи річний план можна планувати робочий час протягом найближчих двох місяців, що дозволяє виявити завдання, які не вирішуються 3 місяця у місяць. Аналогічно $є$ ефективним двотижневий план із визначенням дати, часу і терміну виконання того чи іншого завдання.

У теорії і практиці управління вказується, що під час планування часу доцільно користуватися методом виявлення ключових сфер (ключових проблем і функцій). Менеджер має вирішити, які ключові проблеми варто вважати найважливішими для себе в роботі і особистому житті: родина; емоційний і фізичний стан; друзі, клуб, партія; співпрацівники, підлеглі; покращення технології; фінансові успіхи; становище організації на ринку; організованість і дисциплінованість в роботі; підвищення кваліфікації і т. д. Необхідно визначити, чого менеджер хоче досягти у кожній з ключових проблем протягом тижня, місяця, року. У зв'язку з цим плануються конкретні заходи. Менеджер, що не обмірковує заходи щодо управління часом потрапляє в цейтнот, що у свою чергу викликає психічну напруженість, стрес і незадоволеність результатами роботи.

Дискусія. У практиці управління відомі чинники, що впливають на управління часом і планомірністю роботи менеджера. Одним з таких чинників є млявість - головний ворог успіху у роботі. Причиною млявості є шкідлива звичка менеджера відкладати справи “на потім", а також плутати справи важливі з терміновими. Як правило, млявість у роботі менеджера виникає тоді, коли він зіштовхується з неприємною, невизначеною і неконкретною проблемою. Його поведінка в такій ситуації буває зумовлена багатьма чинниками, а саме: страхом через можливу невдачу; страхом через некомпетентність щодо розв'язання проблеми; страхом перед великим об'ємом роботи; недо- 
статньою привабливістю роботи; незрозумілістю користі від роботи; недостатністю наявної інформації; переконанням недоцільності роботи $[1,5,6]$.

Розгублений і нерішучий менеджер змушений проводити нескінченні консультації, наради, збирати додаткову інформацію, вимагати відстрочок і т. д. Однак, час іде і робота може бути невиконаною у визначені терміни.

Негативно впливають на управління часом систематичні запізнення менеджера, відсутність чітких записів про час нарад, бесід, зустрічей з діловими людьми і своїми співробітниками, недостатня особиста зібраність і пунктуальність у роботі [5]. Водночас дезорганізує діяльність менеджера нераціональне обладнання робочого місця, зокрема: меблі не відповідають ергономічним вимогам; недостатнє освітлення робочого кабінету, дратівливий колір стін; відсутність персонального комп'ютера та іншої оргтехніки, щотижневика, календаря, телефону, селекторного зв'язку. Становище погіршується в результаті низької кваліфікації секретаря (референта, помічника), що негативно впливає на продуктивність праці менеджера $[3,4]$.

Очевидним $\epsilon$ те, що 3 метою управління робочим часом менеджеру необхідно дотримуватися таких правил планування робочого дня: починати день 3 позитивним настроєм; добре поснідати і без поспіху - на роботу; починати роботу в один і той же час; повторно проаналізувати план на день; погодити план на день $з$ секретарем; зранку вирішувати важливі і складні проблем;. фіксувати терміни виконання проблем; відхиляти невідкладні проблеми; уникати незапланованих імпульсивних дій; вчасно робити перерви і дотримуватись розміреного темпу роботи; виконувати невеликі однорідні справи разом; робити перерви між серйозними справами; контролювати час і плани $[1,2]$.

Правила завершення робочого дня: завершуйте розпочате; здійснюйте контроль результатів і самоконтроль; складайте план на наступний день; ідіть додому з гарним настроєм, думайте про найважливішу позитивну подію дня [17].

Аналізуючи роботу, що повторюється і характер кожної дії, менеджер може знайти безліч шляхів для економії часу. Систематична, повсякденна, цілеспрямована робота за планом, чітке визначення і проведення зборів, нарад і засідань 3 детальною підготовкою питань, що обговорюються дозволять значно зменшити витрати часу. Треба домогтися, щоб підлеглі знали годину, день й час прийому, коли і з ким можна вирішувати питання за відсутності менеджера [4].

Якщо менеджер проводить ділову нараду 3 метою колективного обговорення, вироблення правильного рішення і прискорення його реалізації, то можна забезпечити його ефективність і дієвість шляхом таких дій: чіткої підготовки і правильної організації роботи; визначення досить конкретного кола питань для вирішення; запрошення мінімальної кількості фахівців (працівників) з даної проблеми; встановлення чіткого регламенту і стратегії його дотримання [2].

Висновок. Уміння раціонально використовувати робочий час постійно удосконалювати процес його планування - ознака ефективного менеджера. Практичне значення планування особистої роботи менеджера полягає у наступному: воно $\epsilon$ засобом створення ланки між визначенням цілі і більш повним планом іiі реалізації; планування $\epsilon$ єдиним засобом формального прогнозування майбутніх проблем і можливостей; воно полегшує пошук кращих і більш ефективних шляхів досягнення цілей організації, планування виявляє і встановлює зони потенційних проблем і несподіваних наслідків; воно забезпечує основу для оцінки витрат і розробки бюджетів, календарних планів $\mathrm{i}$ ресурсів; планування є основою для контролю; воно допомагає визначити необхідні виробничі взаємодії і взаємовідносини; планування дозволяє передбачити обставини, які варто враховувати під час досягнення цілей. 
1. Гірняк ПП. Менеджмент: Монографія. Київ: Кондор; 2019. 352 с.

2. Дафт РП. Менеджмент. Санки-Петербург: Питер; 2019. 474 с.

3. Десслер Г. Управление персоналом. Киев: Кондор; 2019. 380 с.

4. Коллинз Д, редактор. Лига выдающихся руководителей. Санки-Петербург: Питер; 2020. 208 с.

5. Молл ЕГ. Менеджмент: организационное поведение. Москва: Финансы и статистика; 2020. 380 c.

6. Нестуля ОО. Основи лідерства: монографія. Київ: Кондор; 2019. 358 с.

7. Олкок Д, редактор. Управление временем и робочей нагрузки. Москва: Фин-прес; 2018. 405 c.

8. Тягур РС. Особливості управлінської праці у сфері фізичного виховання і спорту. Вісник Прикарпатського університету. Серія: Фізична культура. 2013; 8: 129-137.

9. Тягур РС. Вимоги, які ставляться до сучасного менеджери у сфері фізичного виховання і спорту. Вісник Прикарпатського університету. Серія: Фізична культура. 2014; 20: 46-52.

10. Тягур РС. Сутність, принципи та напрямки наукової організації праці у сфері фізичного виховання $\mathrm{i}$ спорту. Вісник Прикарпатського університету. Сергія: Фізична культура. 2015; 22: 57-75.

11. Тягур РС. Управління у сфері фізичного виховання: словник базових термінів. Івано-Франківськ: Видавець Віктор Дяків; 2015. 148 с.

12. Тягур РС. Менеджмент в освіті: курс лекції для студентів вищих навчальних закладів. ІваноФранківськ: Видавець Віктор Дяків; 2016. 437 с.

13. Тягур РС. Основи менеджменту у фізичній культурі і спорті: посібник. Івано-Франківськ: Видавець Віктор Дяків; 2016. 144 с.

14. Тягур РС. Розпорядча діяльність керівника у сфері фізичного виховання і спорту (комунікаційноінформаційний аспект). Вісник Прикарпатського університету. Сергія: Фізична культура. 2017; 27: 303-318.

15. Тягур РС. Управління у фізичній культурі і спорті: робочий зошит студента. Івано-Франківськ: Видавець Віктор Дяків; 2017. 172 с.

16. Тягур РС. Педагогічний менеджмент: короткий лекційний курс. Івано-Франківськ: Просвіта, 2018. $65 \mathrm{c}$.

17. Фельзер АБ, Доброневський ОВ. Техніка роботи керівника. Київ: Вища школа; 2019. 408 с.

18. Mintzberg H.The Rise and Fall of Strategic Planning in physical rehabilitation. New York: Free Press, 2018: 54-72.

19. Hart S., Banbury C. Now Strategy Making Process Can Make a Difference, Strategis Management. 2019: 34-58.

20. Marline D. Choice Situation, Strategi, and Performance: A Reexamination,, Strategis Management. 2020: 76-92.

\section{References}

1. Hirniak PP. Management: Monograph. Kiev: Kondor; 2019. 352 s.

2. Daft RP. Management. St. Petersburg: Piter; 2019. 474 s.

3. Dessler G, editors. Personnel Management. Kiev: Kondor; 2019. $380 \mathrm{~s}$.

4. Kollinz D, editors. League of Outstanding Leaders. St. Petersburg: Piter; 2020. 208 s.

5. Moll EG. Management: organizational behavior. Moscow: Finansy i statistika; 2020. $380 \mathrm{~s}$.

6. Nestulia OO. Leadership Basics: A Monograph. Kiev: Kondor; 2019. 358 s.

7. Olkok D, editors. Time and workload management. Moscow: Fin-pres; 2018. 405 s.

8. Tiahur RS. Features of management work in the field of physical education and sports. Newsletter of Precarpathian University. Physical Culture. 2013; 8: 129-137.

9. Тягур PC. Requirements that apply to modern managers in the field of physical education and sports. Newsletter of Precarpathian University. Physical Culture. 2014; 20: 46-52.

10. Tiahur RS. The essence, principles and directions of scientific organization of work in the field of physical education and sport. Newsletter of Precarpathian University. Physical Culture. 2015; 22: 57-75.

11. Tiahur RS. Management in the field of physical education: a dictionary of basic terms. Ivano-Frankivsk: Vydavets Viktor Diakiv; 2015. 148 s.

12. Tiahur RS. Management in Education: Lecture Course for Higher Education Students. Ivano-Frankivsk: Vydavets Viktor Diakiv; 2016. 437 s.

13. Tiahur RS. Fundamentals of Management in Physical Culture and Sports: A Handbook. Ivano-Frankivsk: Vydavets Viktor Diakiv; 2016. 144 s.

14. Tiahur RS. Executive activity of the head in the field of physical education and sports (communicationinformation aspect). Newsletter of Precarpathian University. Physical Culture. 2017; 27: 303-318.

15. Tiahur RS. Management in physical education and sports: student's workbook. Ivano-Frankivsk: Vydavets Viktor Diakiv; 2017. $172 \mathrm{~s}$.

16. Tiahur RS. Pedagogical management: short lecture course. Ivano-Frankivsk: Prosvita, 2018. 65 s. 
17. Felzer AB Dobronevskyi OV. Technique of work of the head. Kiev: Vyshcha Shkola; 2019. $408 \mathrm{~s}$.

18. Mintzberg H.The Rise and Fall of Strategic Planning in physical rehabilitation. New York: Free Press, 2018: 54-72.

19. Hart S., Banbury C. Now Strategy Making Process Can Make a Difference, Strategis Management. 2019: 34-58.

20. Marline D. Choice Situation, Strategi, and Performance: A Reexamination,, Strategis Management. 2020: 76-92.

Цитування на цю статтю:

Тягур РС, Мисів ВМ, Матійчук IB. Менеджер у фізичній культурі: планування особистої діяльності. Вісник Прикарпатського університету. Серія: Фізична культура. 2020 Листоп 24; 36: 74-86

\begin{tabular}{|c|c|}
\hline Відомості про автора: & Information about the author: \\
\hline $\begin{array}{l}\text { Tягур Роман Степанович - кандидат педагогічних } \\
\text { наук, доцент, ДВНЗ “Прикарпатський національ- } \\
\text { ний університет імені Василя Стефаника” (Івано- } \\
\text { Франківськ, Україна) }\end{array}$ & $\begin{array}{l}\text { Tiahur Roman Stepanovych - Candidate of Science } \\
\text { (Education), Associate Professor (Ph. D.), Vasyl Ste- } \\
\text { fanyk Precarpathian National University (Ivano-Fran- } \\
\text { kivsk, Ukraine) }\end{array}$ \\
\hline \multicolumn{2}{|l|}{$\begin{array}{l}\text { e-mail: tyagur.roman@ gmail.com } \\
\text { https://orcid.org/0000-0002-7722-7938 }\end{array}$} \\
\hline $\begin{array}{l}\text { Мисів Володимир Михайлович - кандидат наук } 3 \\
\text { фізичного виховання та спорту, доцент, Кам’янець- } \\
\text { Подільський національний університет імені Івана } \\
\text { Огієнка (Кам'янець-Подільський, Україна) }\end{array}$ & $\begin{array}{l}\text { Mysiv Volodymyr Mykhailovych - Candidate of } \\
\text { Science (Physical Education and Sport), Associate } \\
\text { Professor (Ph. D.), Kamianets-Podilskyi National Ivan } \\
\text { Ohiienko University (Kamianets-Podilskyi, Ukraina) }\end{array}$ \\
\hline \multicolumn{2}{|l|}{$\begin{array}{l}\text { e-mail: mysiv@kpnu.edu.ua } \\
\text { https://orcid.org/0000-0003-1957-0241 }\end{array}$} \\
\hline $\begin{array}{l}\text { Матійчук Ігор Васильович - професор кафедри } \\
\text { спортивно-педагогічних дисциплін, ДВНЗ “При- } \\
\text { карпатський національний університет імені Ва- } \\
\text { силя Стефаника" (Івано-Франківськ, Україна) }\end{array}$ & $\begin{array}{l}\text { Matiichuk Ihor Vasylovych - Professor of the } \\
\text { Department of Sports and Pedagogical Disciplines, } \\
\text { Vasyl Stefanyk Precarpathian National University } \\
\text { (Ivano-Frankivsk, Ukraine) }\end{array}$ \\
\hline e-mail: ihor.matiichuk@pnu.edu.ua & \\
\hline
\end{tabular}

УДК 378.014.6.093.5:796 doi: $10.15330 / f c u l t .36 .86-94$

\section{Сергій Черненко, Олег Олійник,} Юрій Сорокін, Олег Коваль

\section{ХАРАКТЕРИСТИКА ОСВІТНЬОГО ПРОЦЕСУ ПІДГОТОВКИ МАЙБУТНІХ ФХІВЦІВ 3 ФІЗИЧНОЇ КУЛЬТУРИ І СПОРТУ}

Мета. Встановити системність підготовки майбутніх тренерів- викладачів у закладі вищої освіти. Методи. У дослідженні взяли участь 30 студентів першого і 20 другого курсів. Вибір методів, щзо використані в статті, обумовлений логічною моделлю прочесу дослідження, щзо склалася в педагогічній науці. Теоретичний аналіз науково-методичної літератури проводився для вивчення основних концепцій управління підготовки майбутніх фахівц̧ів зі спеціальності 017 - фізична культура $i$ спорт. Вивчення педагогічної та навчально-нормативної документації вищої школи дало змогу встановити проблеми в розумінні студентів процесу освіти в галузі фізичної культури. Анкетування, констатуючий експеримент, методи математичної статистики (графічне відображення даних, аналіз параметрів розподілу) дозволили визначити стан підготовки майбутніх викладачів фізичного виховання у вищому навчальному закладі. Результати. Встановлено, щзо професійно-педагогічна підготовка тренера-викладача спрямована на формування наступних компонентів: мотиваційно-педагогічного (відображає спрямованість, мотиви, потреби в навчанні, иіннісні орієнтації), когнітивно-педагогічного (знання вікової психології, вікових морфо-функціональних особливостей людини), конструктивно-педагогічного (формуванням цілей діяльності, складанням планів і програм, плануванням занять із фізичного виховання і спорту), організаційно-педагогічного (здатність $і$ готовність організовувати навчальнотренувальний процес, управляти і моніторити його ефективність), педагогічно-технологічного (психолого-педагогічні вміння та навички розв 'язувати завдання спортивного тренування дітей і підлітків) та педагогічно-рефлексивного (вміння вивчати, адаптувати і застосовувати кращий досвід в управлінні фізичною підготовкою). Найбільший вплив на професійно-педагогічну мотивацію студентів першого $i$

(C) Черненко С., Олійник О., Сорокін Ю.,

Коваль О., 2020 